\title{
Chromosome numbers of some Brentid and Curculionid weevils from Puerto Rico and the U.S. Virgin Islands ${ }^{1,2}$
}

\author{
Niilo Virkki and Charles W. O'Brien"
}

J. Agric. Univ. P.R. 81(3-4):191-201 (1997)

\begin{abstract}
Chromosomes of 24 curculionoid species from the Greater Puerto Rico Region, including the U.S. Virgin Islands are listed. Seven are endemic and eight are notable agricultural pests. The male meioformula of the broadnosed weevils (Brachyderinae, Otiorhynchinae) as well as of the brentid $C y$ las formicarius elengantulus is the expected $10+\mathrm{Xy}_{\mathrm{p}}$, except for the phyllobiine Lachnopus kofresi from Mona Island $\left(16+\mathrm{Xy}_{\mathrm{p}}\right)$. Representatives of the other curculionid subfamilies had higher autosomal numbers and primitive sex bivalent, $\mathrm{XY}_{\mathrm{p}}$. An exception was Anthonomus eugenii, which has a sex trivalent $\left(X_{1} X_{2} Y\right)^{p}$ in the male. For morphological and cytological reasons, Lachnopus coffeae montanus Marshall, L. seini Wolcott, and L. yaucona Wolcott were synonymized with $L$. coffeae Marshall (NEW SYNONYMIES). One species of Ischionoplus (Brachyderinae) is new to science and it is endemic for Mona Island.
\end{abstract}

Key words: Chromosomes, Coleoptera, Curculionidae, Brentidae

RESUMEN

Números cromosómicos de algunos escarabajos de las familias Brentidae y Curculionidae de Puerto Rico y las Islas Vírgenes de Estados Unidos

Se preparó una lista de los cromosomas de 24 especies de Curculionoidea de la Gran Región de Puerto Rico y de las Islas Vírgenes de U.S.A. Siete especies son endémicas y ocho son plagas notables en la agricultura. La meiofórmula del macho de los picudos de nariz ancha (Brachyderinae, Otiorhynchinae) así como del bréntid Cylas formicarius elengantulus es la esperada $10+\mathrm{Xy}_{p}$, excepto en Lachnopus kofresi de la Isla de Mona $16+$ $x y_{p}$ ). Representantes de otras subfamilias de Curculionidae tienen números autosomales más altos y combinados con el bivalente sexual primitivo $X_{y_{p}}$. Anthonomus eugenii, con su trivalente sexual $\left(X_{1} X_{2} Y\right)$ en el macho, es una excepción. Por razones morfológicas y citológicas los taxones $L$. coffeae montanus Marshall, $L$. seini Wolcott y $L$. yaucona Wolcott fueron sinonimizados con Lachnopus coffeae Marshall (SINONIMIAS NUEVAS). Una especie

'Manuscript submitted to Editorial Board 5 August 1996.

${ }^{2}$ The authors are indebted to Dr. Henri A. Liogier, Taxonomist of the Botanical Garden of the University of Puerto Rico, for identification of many of the food plants.

"Cytogeneticist (now retired), Department of Crop Protection, Agricultural Experiment Station, P.O. Box 21360, Rio Piedras, P.R. 00928.

Professor of Entomology, Entomology-Biocontrol, Florida A \& M University, Tallahassee, FL 32307-4100. 
de Ischionoplus (Brachyderinae) es nueva para la ciencia y es endémica para la Isla de Mona.

\section{INTRODUCTION}

In this paper we list taxonomically chromosomal data collected while investigating how much intraspecific difference Lachnopus curvipes (Curculionidae: Brachyderinae: Barynotini) and Diaprepes abbreviatus (Curculionidae: Otiorhynchinae: Phyllobiini), both notorious agricultural pests, might show in their genetics and cytology. Little has been achieved in this respect (Hantula et al., 1987; Virkki and Sepúlveda, 1990). The broad-nosed curculionids (Brachyderinae and Otiorhynchinae) are not especially inviting subjects for chromosome comparison because of their prevailing diploid number of 22 , and the (male) meioformula of $10+\mathrm{Xy}_{\mathrm{p}}$ (Smith and Virkki, 1978; Takenouchi, 1981), except where parthenogenesis is combined with polyploidy (Suomalainen et al., 1987). However, the large "parachute" sex bivalent $\left(\mathrm{Xy}_{\mathrm{p}}\right)$ of D. abbreviatus and especially of Lachnopus spp., was found suitable for cytochemical studies (Virkki et al., 1990; 1991). Lachnopus curvipes was studied primarily because it was very common. Anthonomus eugenii has $2 \mathrm{n}=31\left(\mathrm{X}_{1}, \mathrm{X}_{2}, \mathrm{y}_{\mathrm{p}}\right) ; 14+\mathrm{X}_{1} \mathrm{X}_{2} \mathrm{y}_{\mathrm{p}}$ ( $\left.{ }^{\star}\right)$ (Bárcenas, 1992).

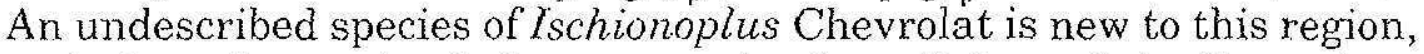
with the only previously known species from Cuba and the Dominican Republic. Chromosomally, it is a typical Brachyderine, with meioformula $10+\mathrm{Xy}_{\mathrm{p}}$. Otherwise, the curculionoid species of Puerto Rico and the Virgin lslands not included in the list remain unknown cytologically.

\section{METHODS}

Living beetles were stored overnight in an icebox at about $20^{\circ} \mathrm{C}$. Testis and ovariole squashes were made, using rapidly fixing KahleSmith fluid (Virkki, 1983 Schedule 5). Most preparations were studied and photographed (Figures 1 to 4 ) with phase contrast optics. If stains were used, they are mentioned in the figure captions. A Zeiss Photomicroscope $\mathrm{II}^{5}$ and Kodak Plus-X Pan $35 \mathrm{~mm}$ film were used throughout.

Instead of meiograms, we have used original photographs to illustrate the list because most of these chromosomes have not been published previously. Karyograms were not prepared because the premeiotic mitoses were scanty.

sTrade names in this publication are used only to provide specific information. Mention of a trade name does not constitute a warranty of equipment or material by the Agricultural Experiment Station of the University of Puerto Rico, nor is this mention a statement of preference over other equipment or materials. 
List of chromosome numbers of some Brentid and Curculionid weevils from Puerto Rico and the U.S. Virgin Islands. Numbers in the column "Islands" refor to footnotes concerning mainly the collection sites and food plants.

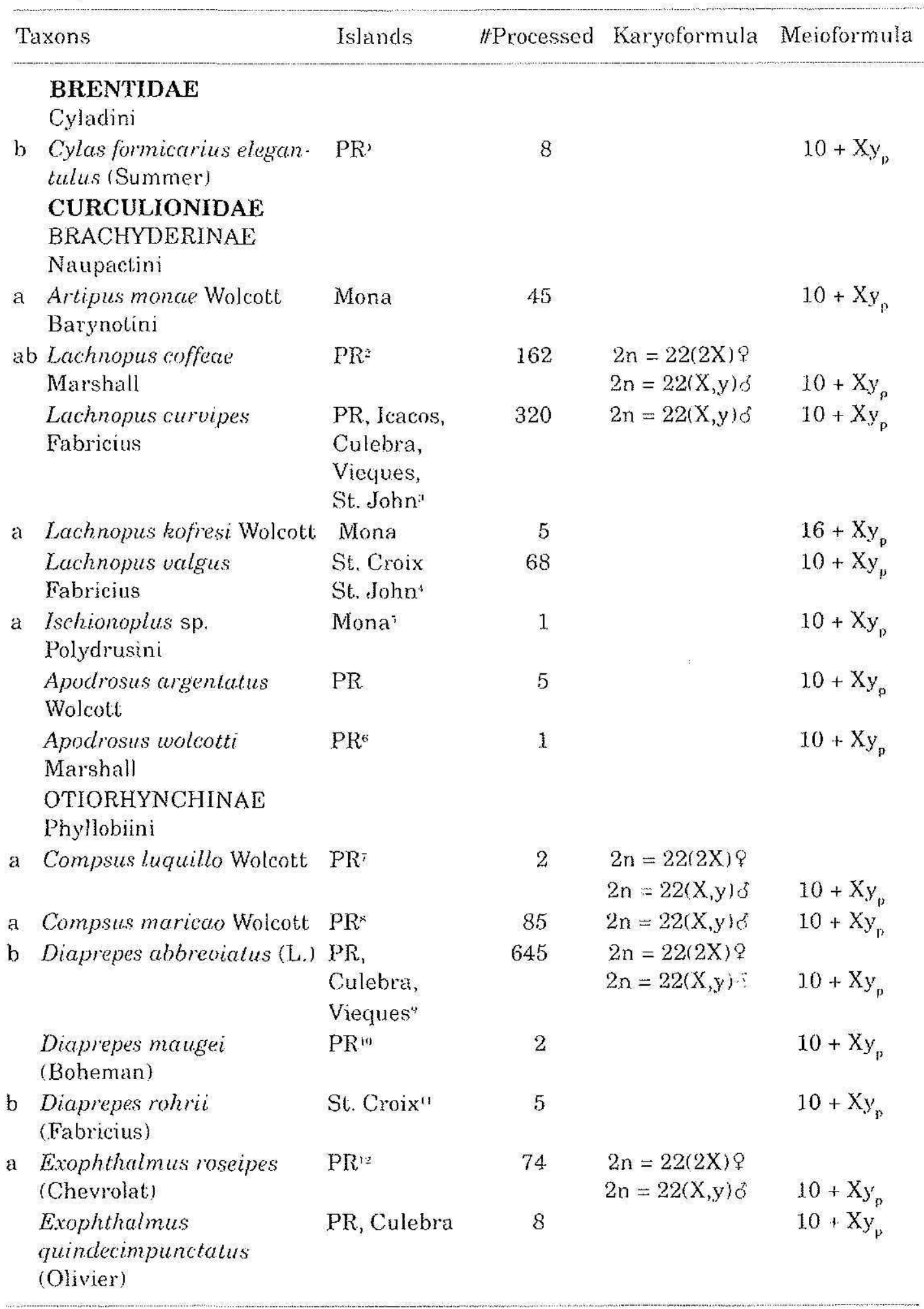


(Continued) List of chromosome numbers of some Brentid and Curculionid weevils from Puerto Rico and the U.S. Virgin Islands. Numbers in the column "Islands" refer to footnotes cancerning mainly the collection sites and food plants.

\begin{tabular}{|c|c|c|c|c|c|}
\hline \multicolumn{2}{|c|}{ Taxons } & Islands & \#Processed & Karyoformula & Meioformula \\
\hline \multicolumn{6}{|c|}{ MOLYTINAE } \\
\hline \multicolumn{6}{|c|}{ Sternechini } \\
\hline & $\begin{array}{l}\text { Siernechus vicinus Flet- } \\
\text { biaux \& Salle }\end{array}$ & PR & 1 & & $10+x y_{12}$ \\
\hline \multicolumn{6}{|c|}{ ANTHONOMINAE } \\
\hline \multicolumn{6}{|c|}{ Anthonomini } \\
\hline b & Anthonomus eugenii Cano & $P R \cdot 4$ & 10 & & $14+X_{1} X_{2} Y$ \\
\hline \multirow[t]{2}{*}{ b } & $\begin{array}{l}\text { Anthonomus flovus Bohe- } \\
\text { man }\end{array}$ & $P R^{\prime:}$ & 10 & & $11+\mathrm{Xy}$ \\
\hline & $\begin{array}{l}\text { CRYPTORHYNCHINAE } \\
\text { Ithyporini }\end{array}$ & & & & \\
\hline \multirow[t]{8}{*}{ b } & $\begin{array}{l}\text { Conotrachelus sapolae } \\
\text { Barber }\end{array}$ & $\mathrm{PR}^{16}$ & 12 & & $20+X y_{k}$ \\
\hline & Cryptorhynchini & & & & \\
\hline & Sternocoelus sp. & $\mathrm{PR}^{\prime 7}$ & 1 & & $16+X y_{p}$ \\
\hline & $\begin{array}{l}\text { BARDDINAE } \\
\text { Peridinetini }\end{array}$ & & & & \\
\hline & Peridinetus signalus & $\mathrm{PR}^{\mathrm{r}}$ & 13 & & $13+\mathrm{XY}_{\mathrm{p}}$ \\
\hline & Rosenschoeld & & & & \\
\hline & RHYNCHOPHORINAE & & & & \\
\hline & Rhynchophorini & & & & \\
\hline \multirow[t]{4}{*}{$b$} & $\begin{array}{l}\text { Cosmopolites sordidus } \\
\text { (Germar) }\end{array}$ & $P R^{\prime:}$ & 4 & & $14+X y_{0}$ \\
\hline & COSSONINAE & & & & \\
\hline & Cossonini & & & & \\
\hline & $\begin{array}{l}\text { Cossonus hamiltoni } \\
\text { Slosson }\end{array}$ & $P R^{2 u}$ & 1.5 & & $17+\mathrm{Xy}_{1}$ \\
\hline
\end{tabular}

$a=$ known from one island only, probably endemic; $b=$ notorious agricultural pest; $\mathrm{PR}=$ Puerto Rico,

1. Isabela Substation (Ipomoea batata). 2. Indiera Alta (Coffea arabicum); Mt. Guilarte; Road 128, Yauco; Barrio Hayales, Coamo (Ropanea coriacea); Road 358, Adjuntas; and elsewhere, from unidentified vegetation. 3. Barrio Hayales, Coamo ( $P$ sidium guayaba); Maunabo (Melicoccus bijugatus); Road 165, Dorado (Dalbergia ecastaphyllum ); Jobos Beach, Isabela (Croton rigidus); Road 10 East, St. John, on a yellow-flowering leguminosae; also from Culebra, Vieques, Icacos, Vacia Talega, Vega Baja, Tortuguero Beach, Yauco, and Yabucoa, on unidentifed vegetation. 4. Road 78, Mt. Eagle, St. Croix (Guapira fragrans); Road 10 East, St. John, from unidentified vegetation. 5. From Citrus sinensis. 6. El Verde. This specimen, identified by the AES entomologists in 1963, has since disappeared from the museum collection. 7. Carite Forest (Cecropia peltata). 8. Road 143, Toro Negro (Miconia pycnoneura); Cerro Maravilla (Rubus rosifolia); Road 388, Adjuntas (Miconia near prasina). 9. Adjuntas Substation (Citrus spp.); Carraízo Alto, Trujillo Alto (Mangifera indica); Catalina nursery, El Yunque (Swietenia mahagoni, Persea americana); Corozal Substation (Citrus spp., Teobroma cacao); Culebra (Cajanus cajan, Croton 
(Continued) List of chromosome numbers of some Brentid and Curculionid weevils from

Puerto Rico and the U.S. Virgin Islands. Numbers in the column "Islands" refer to footnotes concerning mainty the collection sites and food plants.

sp.); Dorado (Citrus sinensis, Persea americana); Fortuna Substation (Persea americana); Barrio Hayales, Coamo (Citrus sinensis, Persea americana); Isabela Substation (Cajanus cajan, Citrus sinensis, Gliricidium sepium, Mangifera indica, Persea americana); Jiménez, El Yunque (Cajanus cajan); Maunabo (Citrus sp.); Vacía Talega (Conocarpus erectus); Vega Baja (Dalbergia ecastaphyllum); Vieques (Mangifera indica); Yabucoa (Andira inermis, Persea americana). In addition, Gurabo, Maricao Forest, Montebello, Rio Piedras, Salinas, Sierra Bermeja, on unidentified vegetation. 10. Cerro Matavilla, Toro Negro (Rubus rosifolius). 11. St. Croix (Citrus sp.). 12. Dorado (Dalbergia ecasta. phyllum); Jobos Beach, Isabela (Croton rigidus); Río Piedras (Andira inermis); Vacía Talega (unknown vegetation). 13. Culebra and Vega Alta (Cruapira fragrans). 14. Isabela Substation (Capsicum frutescens). 15. Carraízo Alto, Trujillo Alto (Malpighia punicifolia). 16. Fortuna Substation (Manilkara zapota). 17. Carraízo Alto, Trujillo Alto (at lights). 18. Juana Diaz, Cabo de Mala Pascua, and Rucio, Peñuelas (Piper spp.). 19. Carraizo Alto, Trujillo Alto (Musa paradisiaca). 20. Road 511, Juana Díaz (Erythrina poeppigiana).

The majority of the species were identified by N. Virkki. Charles W. O'Brien verified these identifications and identified the remainder of the species. All species are vouchered in the latter's private collection in Tallahassee.

\section{REMARKS}

Cylas has been transferred from Curculionidae to Brentidae (Thompson, 1992; Kuschel, 1995). Cylas formicarius elegantulus has the common curculionoid meioformula, $10+\mathrm{Xy}_{\mathrm{p}}$. The sex bivalent, tentatively determined as $\mathrm{Xy}_{\mathrm{p}}$, is exceptional in that the $\mathrm{y}$ chromosome is unusually large. Also the substance keeping $X$ and $y$ together does not stain with the AgNOR technique (Virkki, unpubl.), resembling the substance joining $\mathrm{X}_{2}$ to $\mathrm{y}$ in the sex trivalent of an elaterid, Pyrophorus luminosus (Virkki et al, 1984). Manna and Lahiri (1972) have listed but not illustrated similar chromosome data $\left(2 n=22 ; 10+X y_{p}\right)$ for the Old World C. formicarius.

We use the name Lachnopus Schoenherr 1840, although the names Menoetius Dejean 1821 and Ptilopus Schoenherr 1823 are older because the International Commission of Zoological Nomenclature (ICZN, 1987) has ruled on a proposal by O'Brien and Wibmer (1986) to reject the latter two names and has added the name Lachnopus as the official genus-group name, validating it. All other names follow O'Brien and Wibmer (1982). 

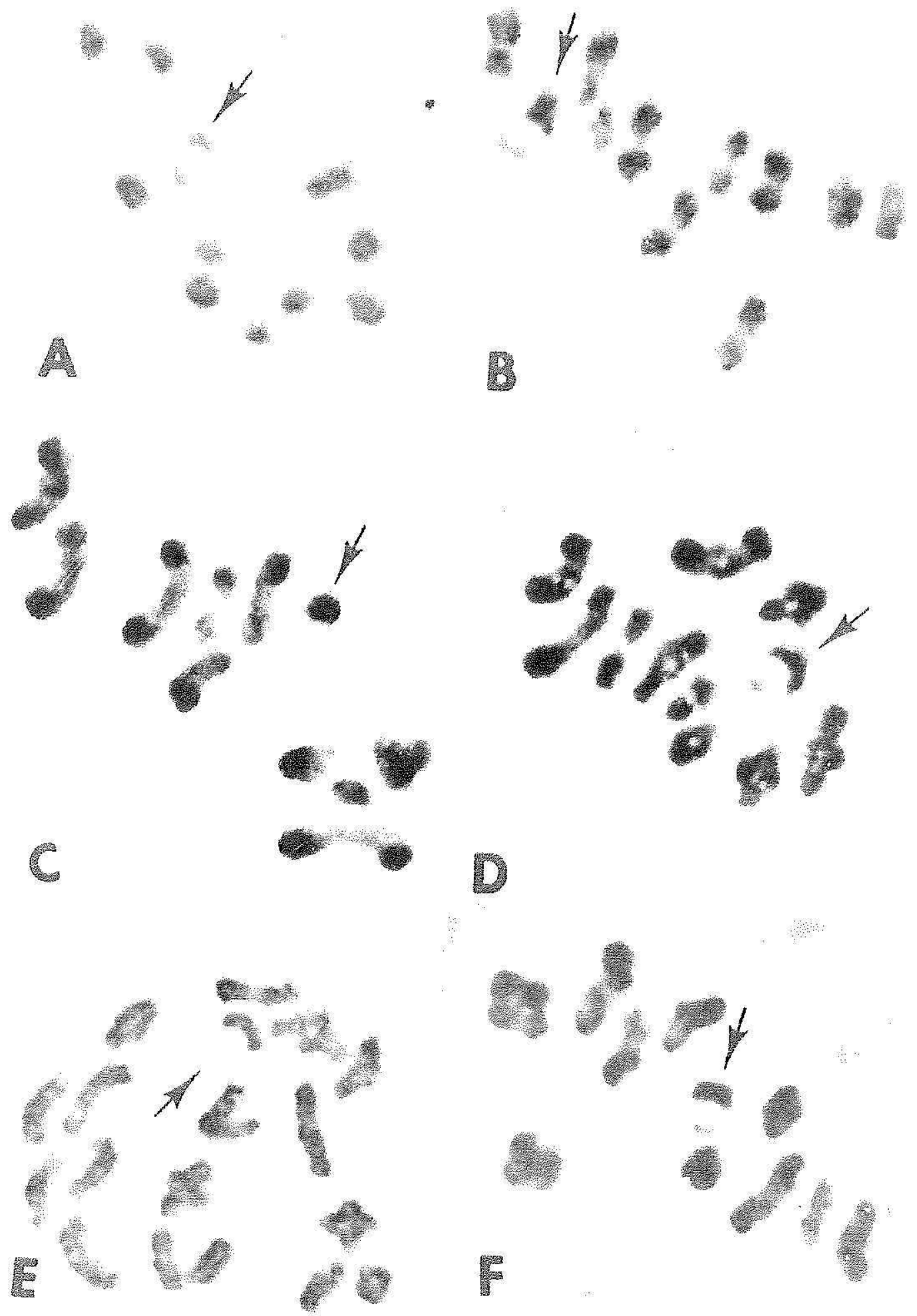

Figure 1. A to F. First meiotic division of male. Except for Lachnopus kofresi, al] show $10+\mathrm{Xy}_{\mathrm{p}}$. Arrow points to the sex bivalent. A. - Cylas formicarius elegantulus. $3032 \mathrm{x}$. B. - Artipus monce. 2507x. C. - Lachnopus coffeae. 2507x. D. - Lachnopus curvipes, 2507x. E. - Lachnopus kofresi. $16+\mathrm{Xy}_{\mathrm{p}}$. 2507x. F. Lachnopus valgus. 2507x. 
J. Agric. Univ. P.R. vOL. 81, NO. 3-4, JULY-OCTOBER 1997
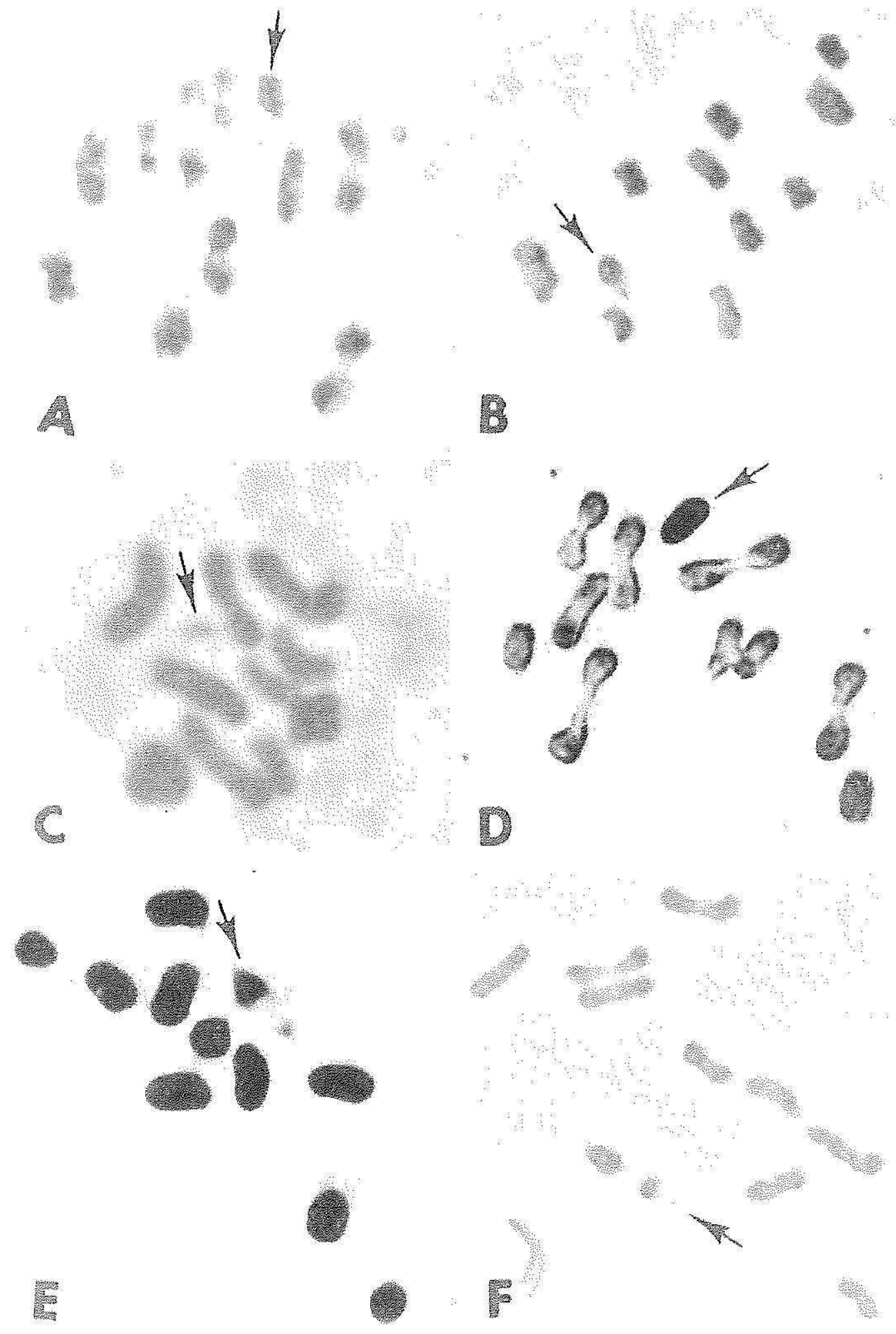

Figure 2. A to F. First metaphase of male meiosis. All show $10+\mathrm{XY}_{1}$. Arrow points to the sex bivalent. A. - Ischionoplus sp. $2337 x$. B. - Apodrosus argentatus. 2337x. C. Aprodosus wolcotti. Acetocarmine. 2900x. D. - Compsus luquillo. Silver staining, normal optics (cf. Virkki et al., 1991). 2507x. E. - Compsus maricao. 2507x. F. - Diaprepes abbreviatus. $1930 \mathrm{x}$. 


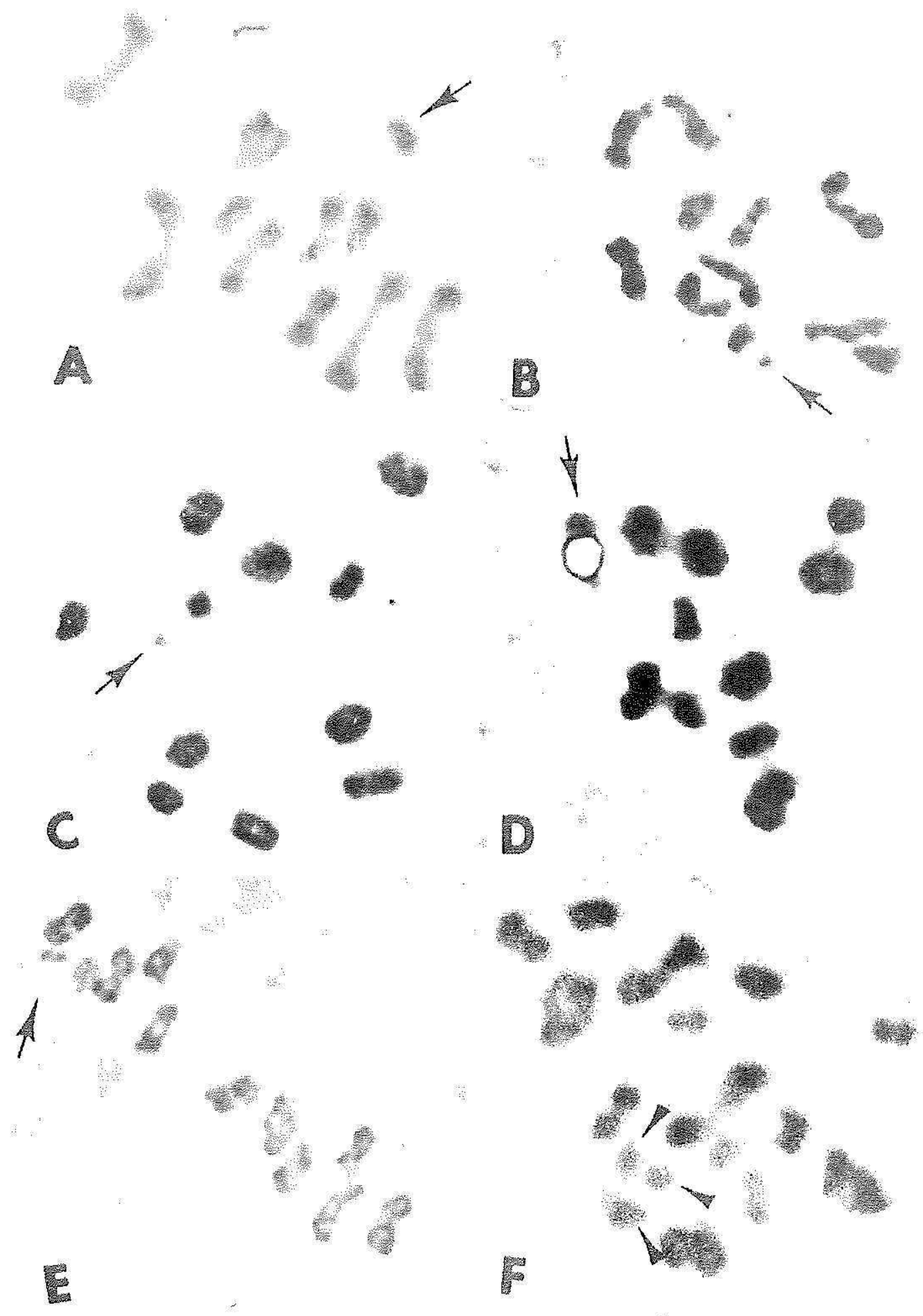

Figure 3. A to F. First meiotic division of male. Arrow points to the sex bivalent in A to E. A. - Diaprepes maugei. $10+\mathrm{Xy}_{1} \cdot 2163 \mathrm{x}$. B. - Diaprepes rohrii. $10+\mathrm{Xy}_{\mathrm{p}} \cdot 2507 \mathrm{x}$. C. - Exophthalmus roseipes. $10+\mathrm{Xy}_{\mathrm{p}}$. 2507x. D. - Exophthalmus quindecimpunctatus. $10+$ $\mathrm{Xy}_{\mathrm{n}}$. Silver staining + phase contrast (cf. Virkki et al., 1991). E. - Sternechus vicinus. 11 $+\mathrm{X}_{\mathrm{p}} .2337 \mathrm{x}$. F. - Anthonomus eugenii. $14+\mathrm{X}_{1} \mathrm{X}_{2} \mathrm{Y}$. Arrowheads point to the three sex chromosomes 4453 . 

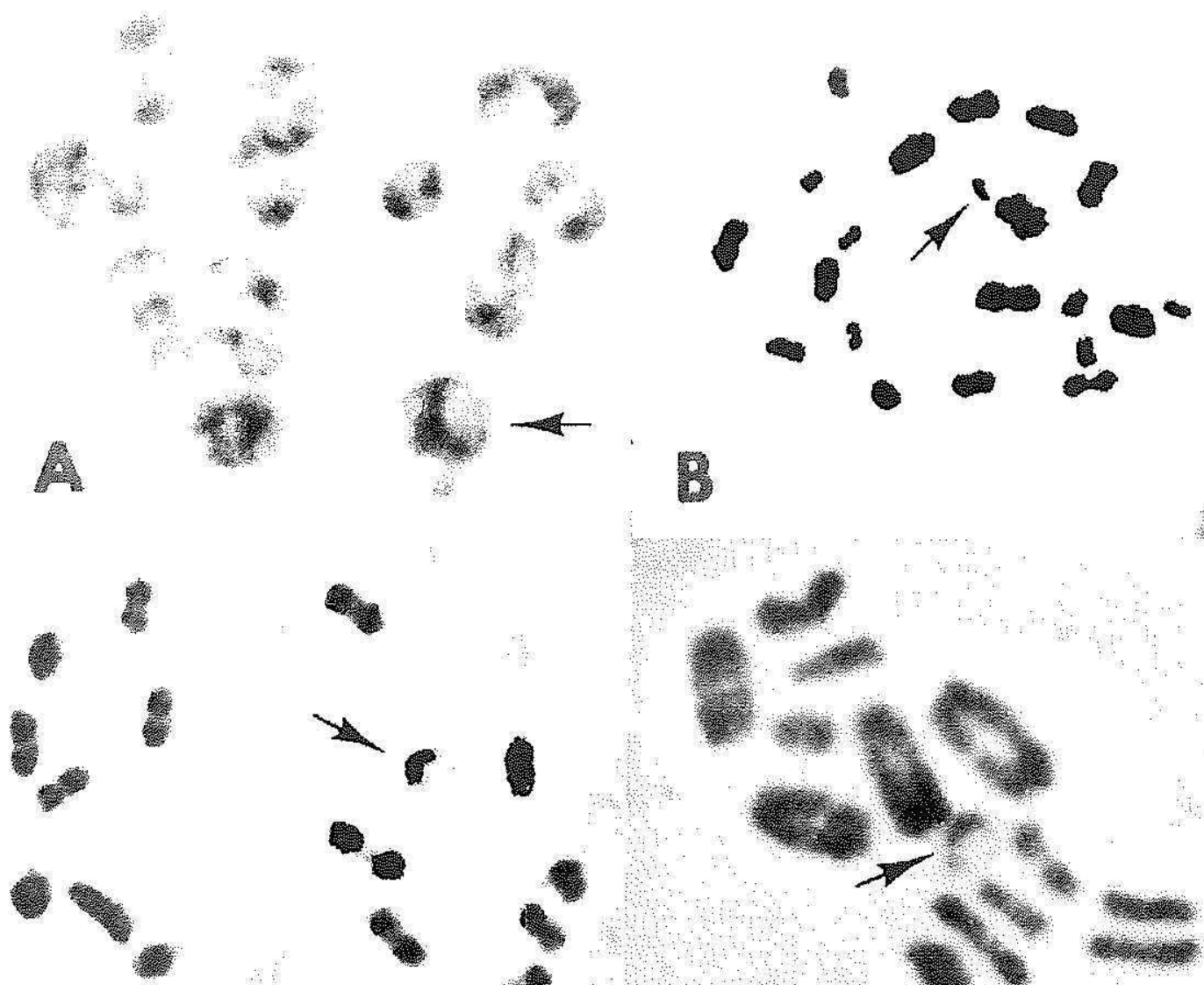

\section{B}
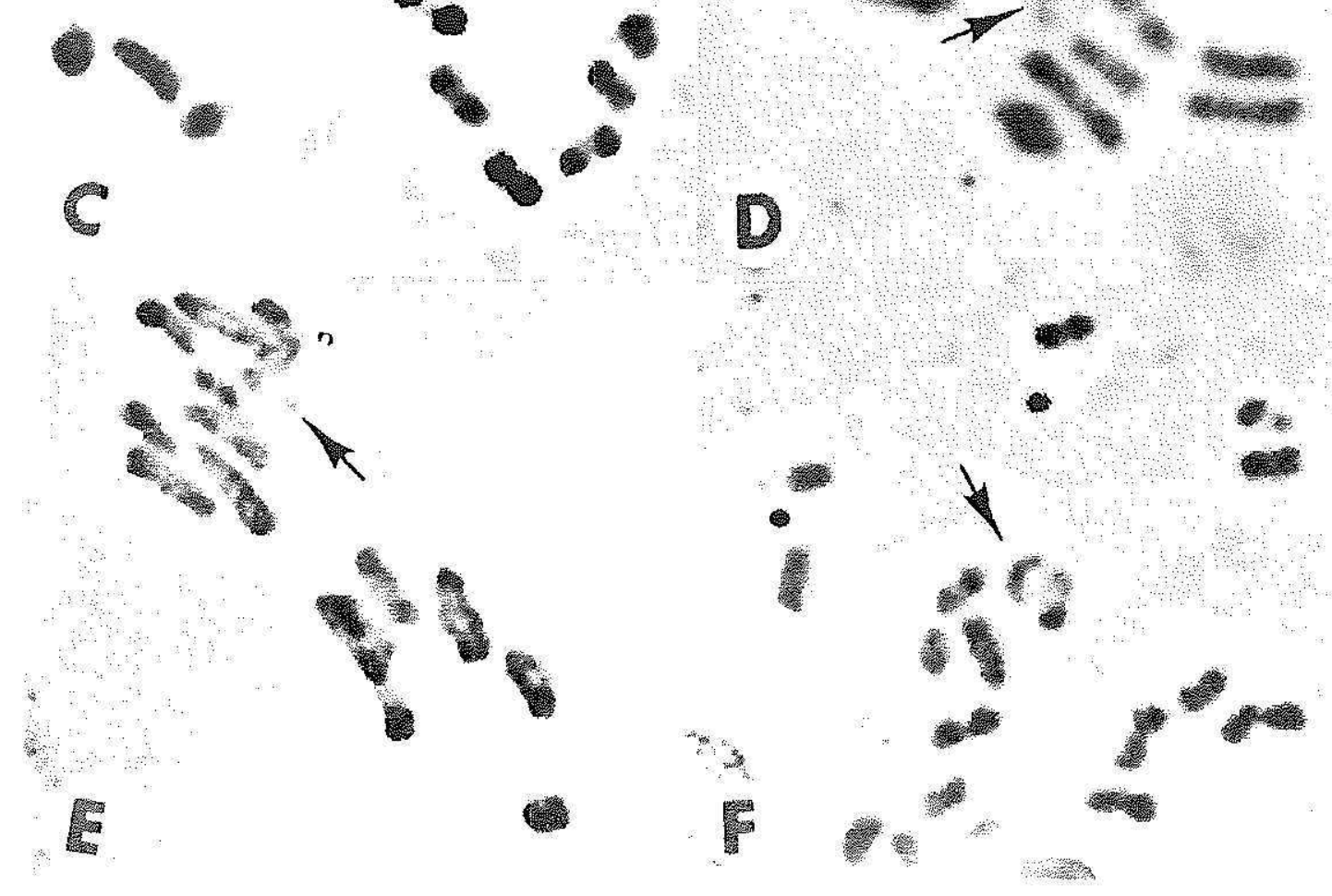

Figure 4. A to F. First meiotic division of male. Arrow points to the sex bivalent. A. - Anthonomous flavus $11+\mathrm{Xy}_{\mathrm{r}}, 4453 \mathrm{x}$. B. - Conotrachelus sapotae. $20+\mathrm{Xy}_{\mathrm{p}}$. 2507x. C. Sternocoelus sp. $16+\mathrm{Xy}_{\mathrm{p}} \cdot 2507 \mathrm{x}$. D. - Peridinetus signatus. $13+\mathrm{X} \mathrm{y}_{\text {. }}$ 2507x. E. - Cosmopolites sordidus. $14+\mathrm{Xy}_{\mathrm{p}} \cdot 2507 \mathrm{x}$. F. - Cossonus hamiltoni. $17+\mathrm{X}_{\mathrm{n}} \cdot 2507 \mathrm{x}$. For silver stain reaction of this $\mathrm{X}_{p}$, see Virkiki et al., 1991. 
Lachnopus seini, L. yaucona and L. coffeae montanus all are synonymized with $L$. coffeae, because we have encountered neither morphological nor cytological evidence to validate these taxa. In view of the cromosomal monotony of Phyllobiini, the elevated chromosome number $\left(16+\mathrm{Xy}_{\mathrm{p}}\right)$ in $L$. kofresi from Mona Island is most intriguing.

The autosomal numbers of Anthonomini vary from 11 to 20 pairs (Bárcenas, 1992; and this present list). The notorious cotton pest, $A$. grandis, has been the subject of the most detailed studies. Wise et al. (1982) and especially Bárcenas (1992) have produced abundant evidence in favor of an $\mathrm{X}_{1} \mathrm{X}_{1} \mathrm{X}_{2} \mathrm{X}_{2} / \mathrm{X}_{1} \mathrm{X}_{2} \mathrm{y}$ sex chromosome system, whereas North et al. (1981) reported an $\mathrm{XY}_{\mathrm{p}}$. Apparently, $20+\mathrm{X}_{1} \mathrm{X}_{2} \mathrm{y}_{\mathrm{p}}\left(\mathrm{y}_{\mathrm{p}}\right.$ because the parachute association mode seems to be retained: Bárcenas, 1992) is the correct meioformula.

Our determination of $14+\mathrm{X}_{1} \mathrm{X}_{2} \mathrm{Y}$ for A. eugenii agrees with that of Bárcenas (1992). The sex chromosomes of A. flavus are very different in size; their mode of association remains obscure.

\section{LITERATURE CITED}

Bárcenas Ortega, N. M., 1992. Cytogenetic and genome size studies of the boll weevi] Anthonomus grandis Boheman and related species (Coleoptera: Curculionidae). Ph.D. Thesis, Texas A\&M University, $119 \mathrm{pp}$.

Hantula, J., A. Saura, J. Lokki and N. Virkki, 1987. Genic and color polymorphism in Puerto Rican phyllobiine weevils Diaprepes abbreviatus (L.) and Compsus maricao Wolcott. J. Agric. Univ. P.R. 71:391-397.

International Commission of Zoological Nomenclature, 1987. Opinion 1451. Lachnopus Schoenherr, 1840 (Insecta, Coleoptera): conserved. Bull. Zool. Nomencl. 44:205206.

Kuschel, G., 1995. A phylogenetic classification of Curculionoidea to families and subfamilies. Mem. Wash. Ent. Soc. 14:5-33.

Manna, G. K. and M. Lahiri, 1972. Chromosome complement and meiosis in forty-six species of Coleoptera. Chrom. Inf. Serv. 13:9-11.

North, D. T., R. A. Leopold and D. Childress, 1981. Meiotic and mitotic chromosomes of the cotton bollweevil. (Coleoptera: Curculionidae). Can. J. Genet. Cytol. 23:443-447.

O'Brien, C. W. and G. J. Wibmer, 1982. Annotated checklist of the weevils (Curculionidae sensu lato) of North America, Central America, and the West Indies (Coleoptera: Curculionidae). Mem. Am. Entomol. Inst. 34:i-ix, 1-382.

O'Brien, C. W. and G. J. Wibmer; 1986. Lachnopus Schoenherr, 1840. (Insecta, Coleoptera): Proposed conservation by the supression of Menoetius Dejean, 1821 and Ptilopus Schoenherr, 1823. Z.N.(S.). 2487. Bull. Zool. Nomencl. 43:62-65.

Smith, S. G. and N. Virkki, 1978. Animal Cytogenetics. Coleoptera. Edit B. John. Borntraeger, Berlin-Stuttgart, 366.pp.

Suomalainen, E., A. Saura and J. Lokki, 1987. Cytology and evolution in parthenogenesis. CRC Press, Florida, 216. pp.

Takenouchi, Y., 1981. Chromosome numbers of Japanese weevils of Curculionoidea (C0leoptera). Seibuzu-kyozai 16:155-170.

Thompson, R. A., 1992. Observations on the morphology and classification of weevils (Coleoptera, Curculionoidea) with a key to major groups. J. Nat. Hist. 26:835-891. 
Virkki, N., 1983. Banding of Oedionychina (Coleoptera: Alticinae) chromosomes: C- and Ag-banding. J. Agric. Univ. P. R. 67:221-255.

Virkki, N., M. Flores and J. Escudero, 1984. Structure, orientation and segregation of the sex trivalent in Pyrophorus luminosus III. (Coleoptera, Elateridae). Canad. J. Genet. Cytol. 26:326-330.

Virkki, N., C. Mazzella and A. Denton, 1991. Silver staining of the coleopteran Xy bivalent. Cytobios 67:45-63.

Virkki, N., C. Mazzella and A. Denton, 1990. Staining of substances adjacent to the sex bivalent in certain weevils of Puerto Rico. J. Agric. Univ. P.R. 74:405-418.

Virkki, N. and J. M. Sepúlveda, 1980. Chromosomes of the Puerto Rican "vaquita" Diaprepes abbreviatus (L.) (Curculionidae: Otiorrhynchinae: Phyllobiini). J. Agric, Univ. P.R. 74:121-132.

Wise, D. J., J. M. Wright and J. R. McCoy, 1982. Meiotic chromosomes of the boll weevil. J. Heredity 73:234-236. 